\title{
APLIKASI INVERSI MODEL BASED DAN STOKASTIK UNTUK MEMETAKAN PERSEBARAN RESERVOIR BATUPASIR
}

\author{
Gestin Mey Ekawati, S.T., M.T. ${ }^{1}$, Ignatius Sonny Winardhi, Ph.D ${ }^{2}$ \\ ${ }^{1}$ Institut Teknologi Sumatera \\ ${ }^{2}$ Institut Teknologi Bandung
}

\begin{abstract}
:
Lapangan " $M$ " terletak di Cekungan Sumatra Selatan. Target reservoir berada pada Talang Akar Formation (TAF) yang merupakan reservoir batupasir dengan lapisan keseluruhannya adalah perselingan antara batupasir dan shale serta sisipan batubara. Lapisan batupasir pada TAF memiliki ketebalan yang tipis sekitar $13.5 \mathrm{~m}$ dan berada di bawah tuning thicknes. Pada penelitian ini penulis mengaplikasikan metode inversi seismik deterministik dan stokastik untuk mengatasi lapisan tipis. Metoda inversi deterministik model based dijadikan model awal/ soft constraint dalam inversi stokastik. Inversi model based menghasilkan hasil yang sesuai dengan data sumur, namun hasilnya masih cenderung smooth dan blocky sehingga belum mampu meresolusi lapisan tipis dengan baik. Inversi seismik stokastik diaplikasikan untuk mengatasi kekurangan yang ada pada inversi seismik deterministik khususnya pada kasus lapisan tipis. Dari realisasi-realisasi model impedansi hasil inversi stokastik yang telah dihasilkan, penulis membuat suatu model probabilitas pada selang impedansi tertentu, dalam hal ini ialah selang impedansi batupasir sehingga penyebaran dari batupasir dapat terlihat. Model probabilitas dari 30 realisasi inversi stokastik dengan parameter $P$-Impedance dapat memetakan persebaran reservoir batupasir di lapangan " $M$ " dengan cukup baik. Peta probabilitas batupasir maksimum berada pada bagian utara daerah penelitian.
\end{abstract}

Keyword: tuning thickness, inversi seismik model based, inversi seismik stokastik

\section{Pendahuluan}

Dalam penelitian ini, penulis melakukan penelitian di daerah lapangan " $M$ " yang terletak di Sub Cekungan Palembang Selatan yang berada pada bagian selatan Cekungan Sumatera Selatan. Cekungan Sumatera Selatan merupakan cekungan busur belakang (back arc basin) berumur tersier yang terbentuk karena interaksi Paparan Sunda atau lempeng kontinen Asia dengan lempeng

Samudera Hindia.

Cekungan Sumatera Selatan terbagi menjadi tiga fase tektonik.

1. Pada periode Pra-Tersier, masa Mesozoikum Tengah terjadi proses orogenesa yang menyebabkan terjadinya metamorfosa batuan-batuan endapan Pleozoikum dan gejala yang terjadi membentuk rangka struktur Pulau Sumatera.

2. Pada periode Akhir Kapur - Awal Tersier terbentuk struktur geologi berupa graben dan blok sesar yang diakibatkan oleh gaya tarik (tension). Struktur tersebut terbentuk di Cekungan Sumatera dan di Cekungan Sunda. Secara umum arah trend dari sesar dan graben berarah utara - selatan dan barat laut- tenggara.

3. Pada periode Awal Tersier sampai Miosen, kala Plio-Plistosen terjadi proses orogenesa yang menghasilkan struktur geologi berupa sesar dan lipatan yang mempunyai arah barat laut. Proses konvergen antara lempeng Samudera Hindia dengan Sumatera (bagian dari lempeng Asia Tenggara) menyebabkan terangkatnya Bukit Barisan. Struktur membentuk struktur muda (young structure), struktur yang dominan yang ada pada Cekungan Sumatera kemudian diikuti proses penurunan cekungan dan pengendapan sedimen Tersier. 


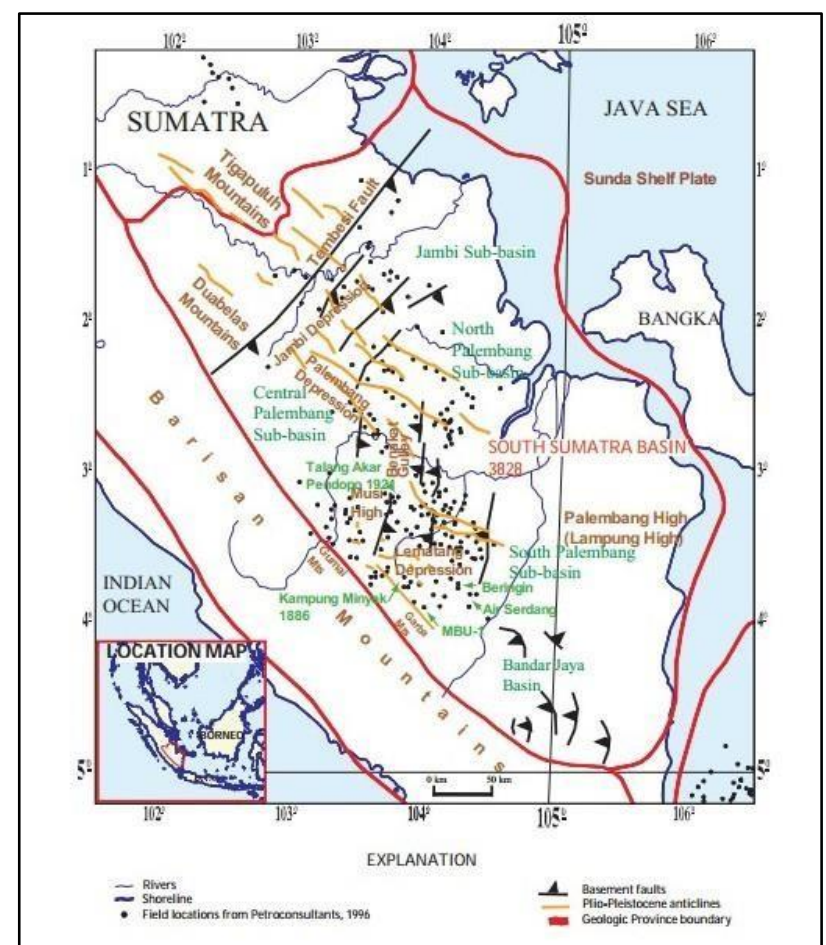

Gambar 1. Peta Cekungan Sumatera Selatan dengan struktur utama secara regional (Bishop, 2001)

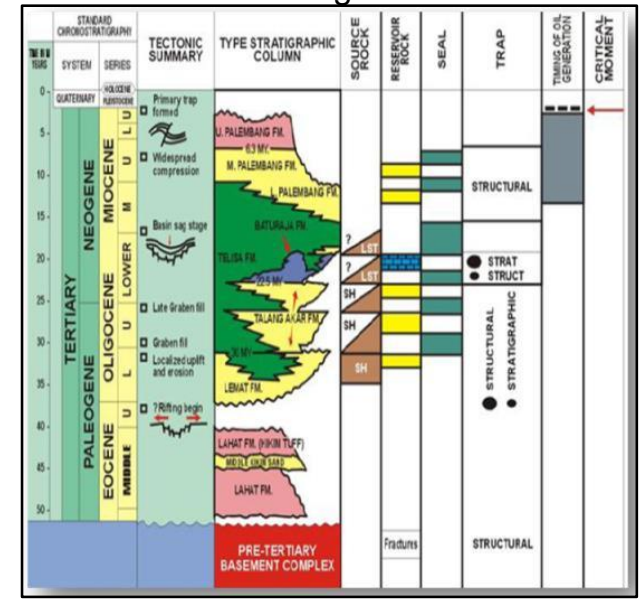

Gambar 2. Kolom stratigrafi Cekungan Sumatera Selatan (De Coster, 1974)

Target reservoir berada pada Talang Akar Formation (TAF) yang merupakan reservoir batupasir. Lapisan batupasir pada TAF memiliki ketebalan yang tipis sekitar $13.5 \mathrm{~m}$ dan berada di bawah tuning thickness sehingga akan menjadi masalah pada saat interpretasi.

\subsection{Data}

\section{Data dan Metode}

Data seismik yang digunakan adalah data seismik post-stack dengan geometri inline 1 sampai 516 dengan spasi $25 \mathrm{~m}$ dan geometri crossline 1 sampai 992 dengan spasi $12.5 \mathrm{~m}$. Sampling interval data seismik 2 ms. Data horison antara lain: Top_BRF_upd (biru),Top_TAF_upd (kuning),Top_BSMT_upd (merah). Data horison merupakan hasil picking dari penelitian sebelumnya. Target yang dianalisis yaitu Talang Akar Formation (TAF) yang dibatasi oleh horison Top_TAF_upd - Top_BSMT_upd. 

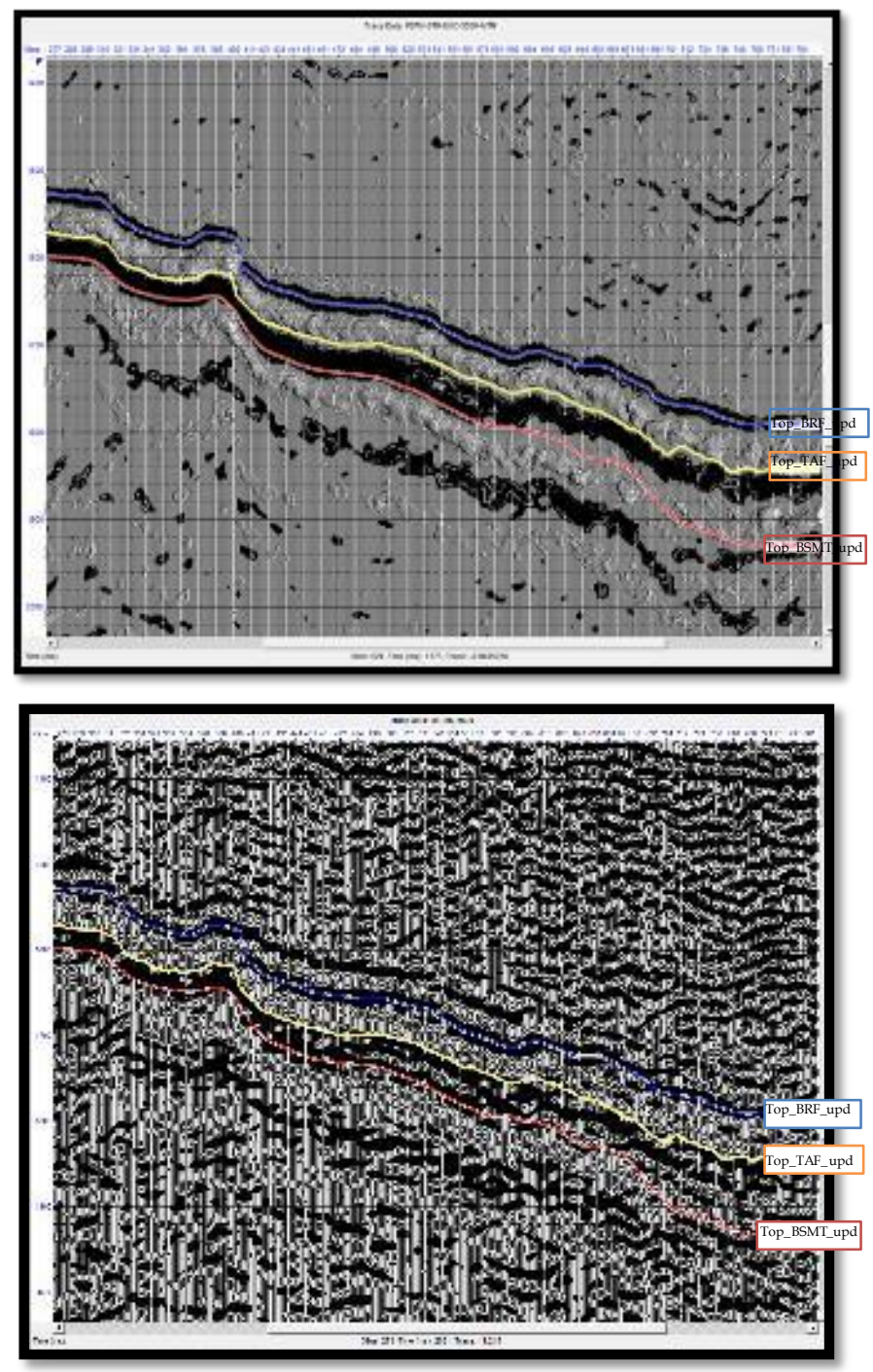

Gambar 3. Data seismik post stack 3D sebelum enhancement (atas) dan setelah enhancement (bawah)

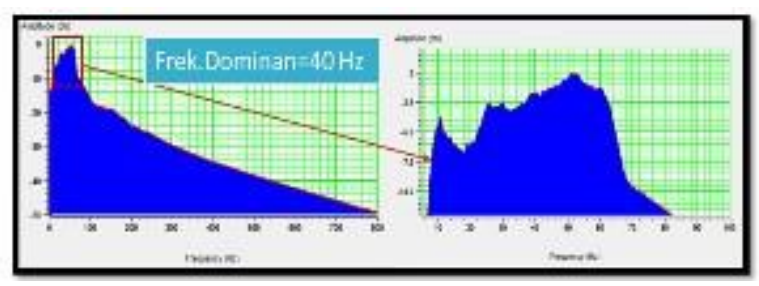

Gambar 4. Frekuensi dan amplitude spectrum seismik setelah proses enhancement (Frekuensi setelah enhancement sebesar $40 \mathrm{~Hz}$ dan sebelum enhancement sebesar $15 \mathrm{~Hz}$ )

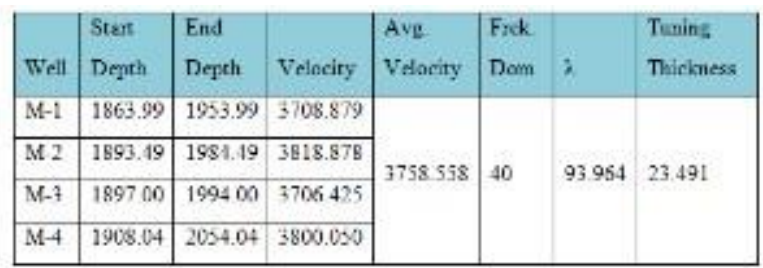

Tabel 1. Tabel perhitungan tuning thickness

Proses enhancement dilakukan dengan menggunakan metode spectral whitening. Hasil perhitungan tuning thickness setelah proses enhancement seismik sebesar 23.491 m sedangkan reservoir batupasir 
di daerah target memiliki ketebalan 13.5 m sehingga dapat disimpulkan target berada di bawah tuning thickness.

Sumur yang digunakan dalam penelitian ini adalah sumur M-1, M-2, M-3, dan M-4.

\begin{tabular}{|c|c|c|c|c|}
\hline \multirow{2}{*}{ Data Log } & \multicolumn{4}{|c|}{ Weil } \\
\hline & $\mathrm{N}-1$ & $n-2$ & H-3 & M-4 \\
\hline Gamma-ray & " & $v$ & $v$ & $v$ \\
\hline Densiles & " & v & v & $v$ \\
\hline Poresty & v & v & $v$ & $v$ \\
\hline Neurron perosity & $v$ & $v$ & $v$ & $v$ \\
\hline Resistbinty & v & $v$ & $v$ & $\checkmark$ \\
\hline SP & " & v & $v$ & $v$ \\
\hline Wolure stale & v & v & $v$ & $v$ \\
\hline $\mathrm{SW}$ & " & $v$ & - & $v$ \\
\hline$v p$ & " & v & $v$ & $v$ \\
\hline is & - & - & - & - \\
\hline Cheskshot & - & - & $v$ & $v$ \\
\hline$x$ & 426046.00 & 428231.00 & 42717140 & 427330.00 \\
\hline Y & 9589223.90 & 9590525.00 & 9585036.50 & 9593618.00 \\
\hline
\end{tabular}

Tabel 2. Data sumur M-1, M-2, M-3, dan M-4

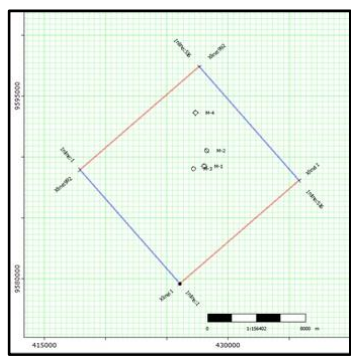

Gambar 5. Basemap daerah penelitian

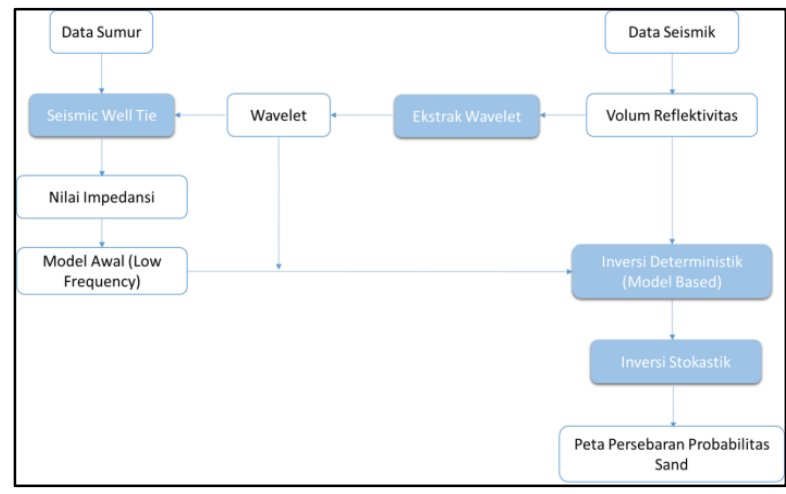

Gambar 6. Alur kerja penelitian

Untuk melakukan well seismic tie dibutuhkan data marker, horison, checkshot, Vp serta wavelet estimasi. Wavelet yang digunakan dalam proses well seismic tie pada penelitian ini adalah wavelet hasil ekstraksi metode statistik dari seismik karena menghasilkan nilai korelasi yang paling optimal.

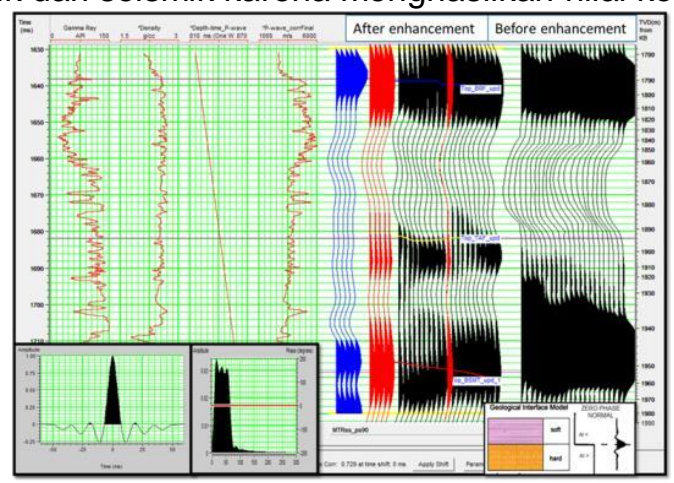



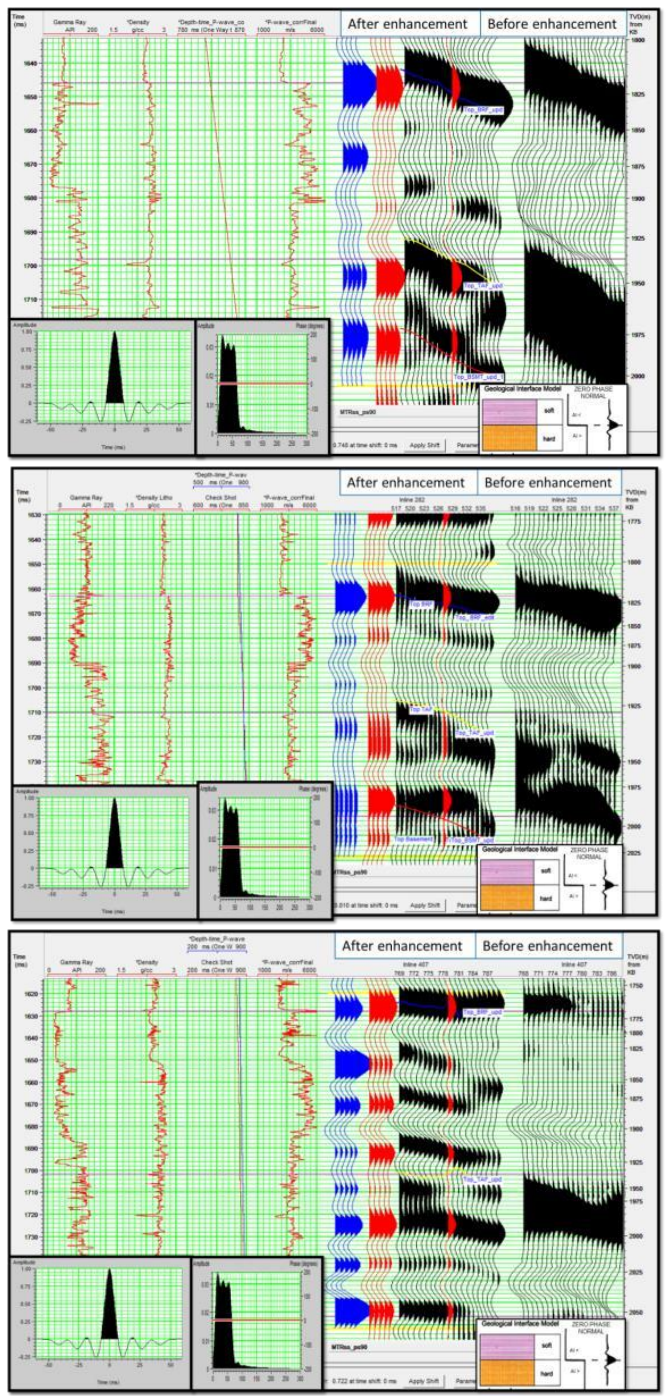

Gambar 7. Hasil well seismic tie pada sumur M-1 (korelasi=0.729), M-2(korelasi=0.748), M$3($ korelasi $=0.810), \mathrm{M}-4($ korelasi $=0.722)$

\subsection{Data}

Inversi Seismik Deterministik

Metode inversi seismik deterministik didasarkan pada prinsip minimalisasi error antara data seismik dengan data sintetik yang didapat melalui forward modelling dari data sumur.

Inversi seismik deterministik yang digunakan adalah inversi seismik model based. Inversi seismik deterministik digunakan sebagai model awal/ soft constraint untuk melakukan inversi stokastik dan juga digunakan sebagai pembanding hasil inversi stokastik.

Inversi Model Based merupakan salah satu modul inversi post stack yang terdapat pada software Hampson-Russel (HRS). Pada penelitian ini dilakukan inversi model based untuk setiap sumurnya yang kemudian hasil inversi dari empat sumur tersebut diambil average hasil inversinya sehingga hasilnya akan lebih baik. Untuk proses inversi model based diperlukan suatu model impedansi frekuensi rendah yang didapat dari sumur. Model ini dibuat untuk mengisi nilai frekuensi rendah yang tidak hadir pada spektrum frekuensi data seismik sehingga dapat memberi jangkauan frekuensi yang lebih lebar dari data seismik yang bandlimited. Model dibuat dengan frekuensi rendah 10/15 Hz. 


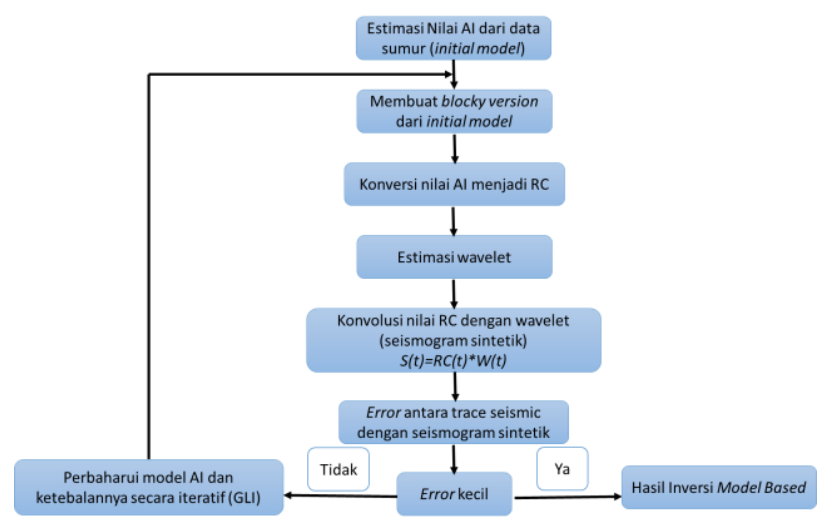

Gambar 8. Flowchart inversi model based

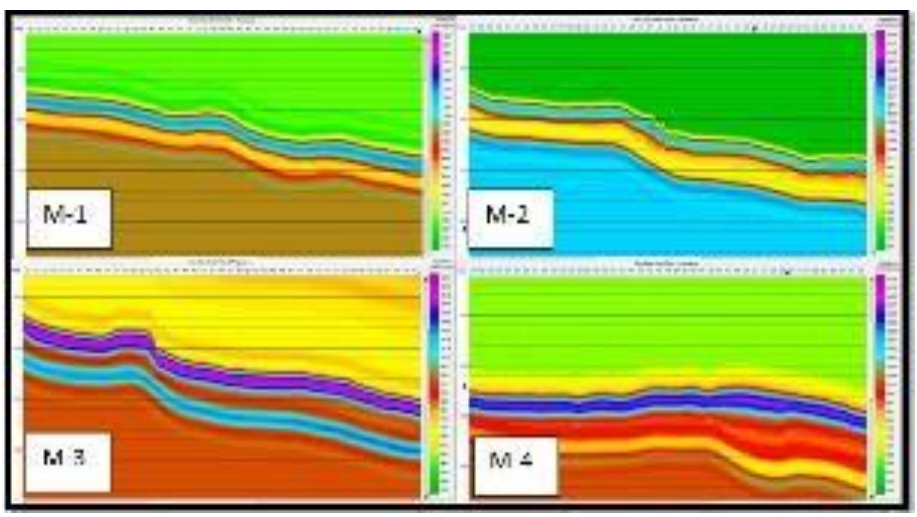

Gambar 9. Initial model (sumur M-1, M-2, M-3, M-4)

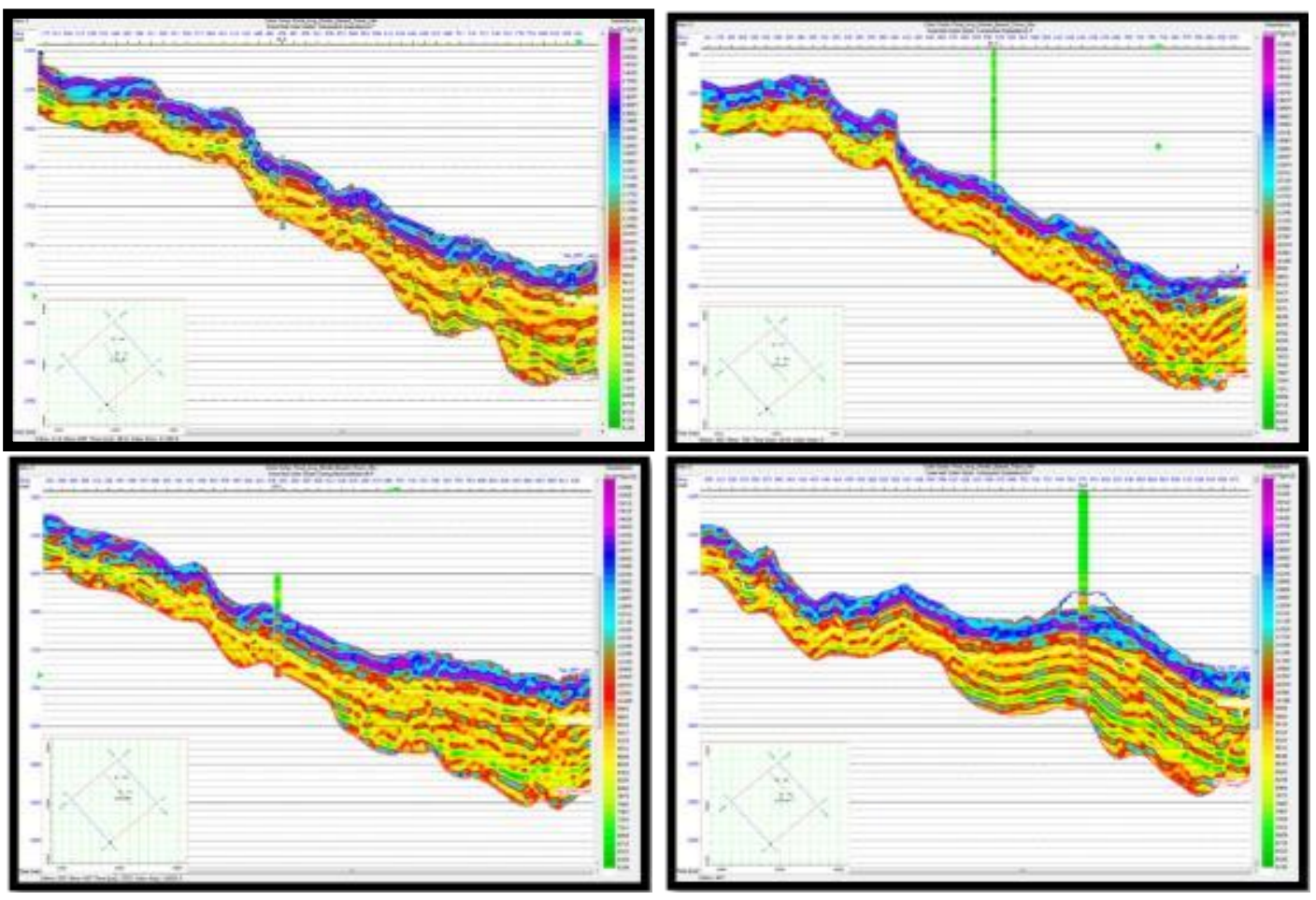

Gambar 10. Hasil inversi model based melewati sumur M-1, M-2, M-3, M-4 
Inversi Seismik Stokastik

Inversi seismik stokastik merupakan teknik inversi yang prinsip dasarnya menggunakan suatu algoritma simulasi acak dan menghasilkan lebih dari satu model impedansi akustik yang memenuhi data seismik observasi. Solusi lebih dari satu ini dapat mengatasi masalah non-uniqueness dan uncertainty pada inversi deterministik khususnya dalam kasus lapisan tipis. Kelebihan lainnya adalah metode ini tidak tergantung pada bandwidth data seismik yang digunakan melainkan pada ukuran blok saat mensimulasi model impedansi sehingga hasil dari inversi stokastik ini lebih tidak smooth dibandingkan dengan hasil inversi deterministik.

Prinsip dasar dari inversi seismik stokastik ini adalah prinsip Bayesian. Prinsip ini menggunakan konsep probabilitas yang diinterpretasikan sebagai "a measure of a state of knowledge" (H.Anders, 1998). Prinsip ini merupakan suatu prinsip probabilitas, dimana terdapat suatu model probabilitas prior, yang kemudian diformulasikan dengan suatu fungsi probabilitas likelihood sehingga mendapatkan keluaran model probabilitas posterior. Model keluaran ini merupakan realisasi-realisasi atas model impedansi. Perumusan prinsip Bayesian adalah sebagai berikut :

dimana:

$$
\sigma(m)=k \cdot \rho(m) \cdot L(m)
$$

$\sigma(m)$ : model posterior

$\rho(m) \quad$ : model prior $\mathrm{L}(\mathrm{m})$

$L(m) \quad$ : fungsi likelihood

k : konstanta

Pengolahan data untuk proses inversi seismik stokastik dilakukan dengan menggunakan software lkon Rokdoc. Realisasi model impedansi hasil inversi seismik stokastik yang dihasilkan sebanyak 30 realisasi.

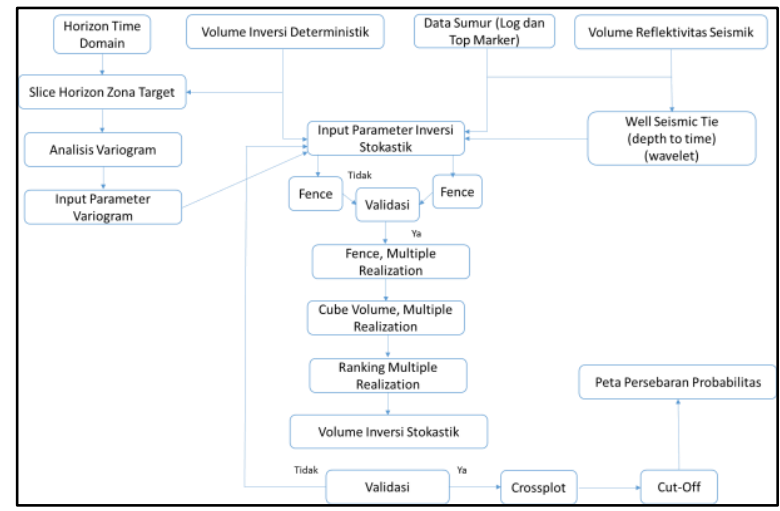

Gambar 11. Alur kerja inversi seismik stokastik

Analisis variogram

Analisis variogram dilakukan untuk memperlihatkan hubungan spasial antar data pada proses inversi seismik stokastik. Analisis variogram yang dilakukan adalah variogram horizontal. Variogram horizontal dihitung dengan menggunakan hasil sayatan antara horison daerah target yaitu Top_BRF_updTop_TAF_upd dan Top_TAF_upd-Top_BSMT_upd. Sedangkan untuk variogram vertikal digunakan sampling rate dari data sumur sebesar $1 \mathrm{~m}$.

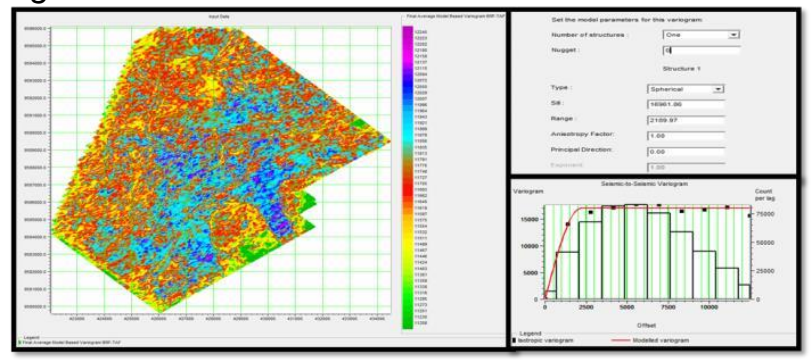

Gambar 12. Hasil irisan penampang pada daerah target diantara horison

$$
\text { Top_BRF_updTop_TAF_upd }
$$




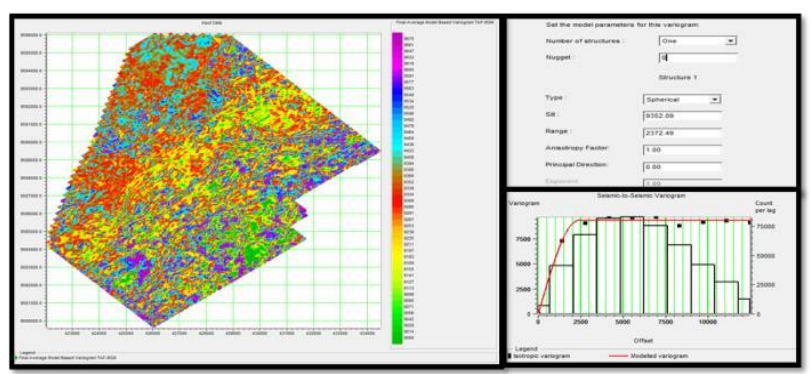

Gambar 13. Hasil irisan penampang pada daerah target diantara horison Top_TAF_upd-

$$
\text { Top_BSMT_upd }
$$

Berdasarkan analisis variogram yang dilakukan, didapatkan nilai range adalah sebesar 2189.97 untuk zona antara horizon Top_BRF_upd-Top_TAF_upd dan 2372.49 untuk zona antara horizon Top_TAF_upd-Top_BSMT_upd.

Input data yang digunakan untuk menghasilkan realisasi-realisasi inversi stokastik antara lain adalah model inisial, hasil seismik deterministik, data reflektivitas seismik, batasan nilai impedansi dari data log sumur, dan banyaknya realisasi.

Pada penelitian kali ini, banyaknya realisasi yang dihasilkan adalah 30 realisasi dengan batasan nilai impedansi untuk $P$-Impedance antara $6136-15398(\mathrm{~m} / \mathrm{s})^{*}(\mathrm{~g} / \mathrm{cc})$.

Hasil inversi seismik stokastik realisasi 1 , realisasi 15 dan realisasi 30 yang melewati sumur $M-1, M-2$, M-3, dan M-4 sebagai berikut:

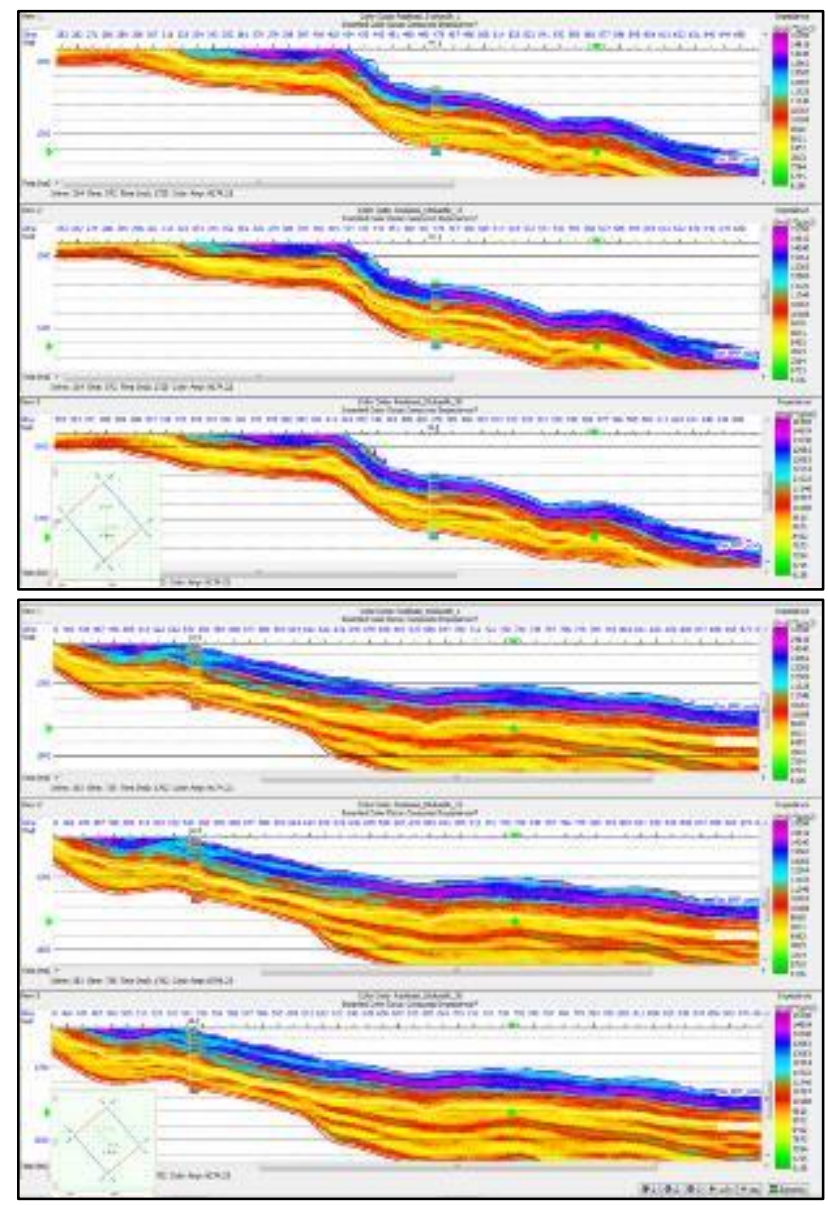




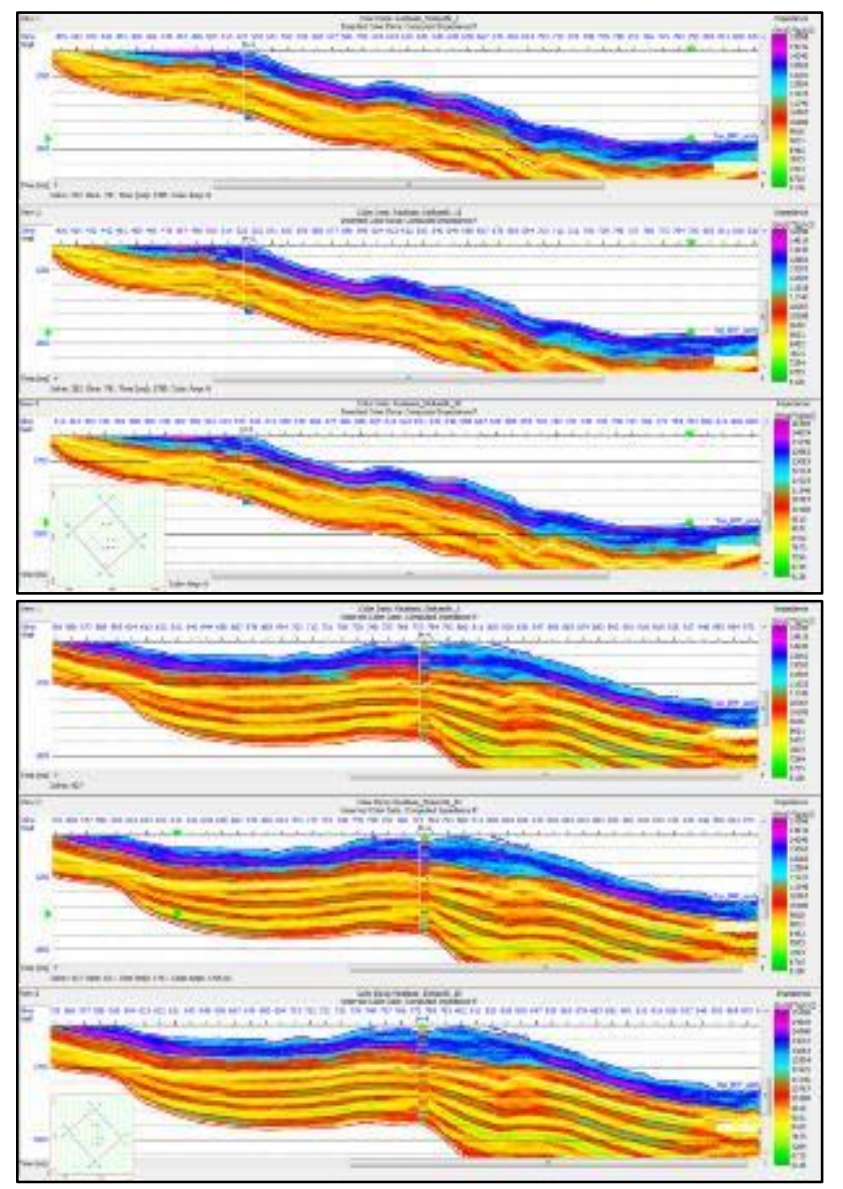

Gambar 14. Inversi seismik stokastik yang melewati sumur M-1, M-2, M-3, M-4

\section{Probabilitas}

Setelah memperoleh 30 realisasi hasil inversi stokastik, kemudian dibuat suatu model probabilitas dari batupasir target. Probabilitas diperoleh dari seluruh realisasi model impedansi stokastik. Model probabilitas ini hanya akan memperlihatkan nilai probabilitas untuk range impedansi akustik batupasir. Untuk mengetahui persebaran batupasir diperlukan penentuan cut-off nilai impedansi $P$-Impedance yang didapatkan dari hasil crossplot antara nilai log dan nilai hasil inversi seismik stokastik. Nilai cut-off dijadikan nilai batas untuk menghasilkan probabilitas batupasir. Adapun nilai cut-off $P$-Impedance untuk batupasir adalah $10000(\mathrm{~m} / \mathrm{s})^{*}(\mathrm{~g} / \mathrm{cc})$.

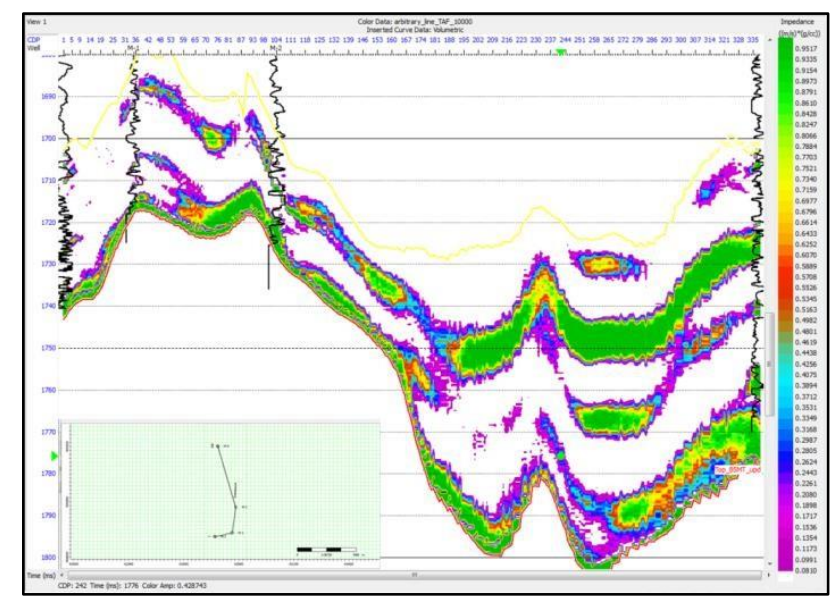

Gambar 15. Model Probabilitas batupasir berdasarkan nilai $P$-Impedance pada arbitrary line dengan kurva $V$-shale 


\section{Hasil dan analisis}

Analisis sensitivitas dilakukan pada sumur M-1, M-2, M-3, dan M-4. Penulis melakukan crossplot antara dua parameter yaitu P-Impedance dan V-shale dengan gamma ray sebagai color key. Analisis sensitivitas dilakukan untuk mengetahui parameter mana pada sumur yang sensitif terhadap perubahan litologi. Pada penelitian kali ini kehadiran batupasir overlapping dengan shale di zona target atau pada Talang Akar Formation sehingga batupasir dengan shale sangat sulit dipisahkan.

Pendekatan yang dilakukan penulis untuk memisahkan batupasir dengan shale yaitu dengan melihat kandungan V-shale. Jika V-shale kurang dari $0.4(40 \%)$ maka batuan tersebut dikategorikan sebagai batupasir, jika lebih dari 0.4 maka dianggap sebagai shale.

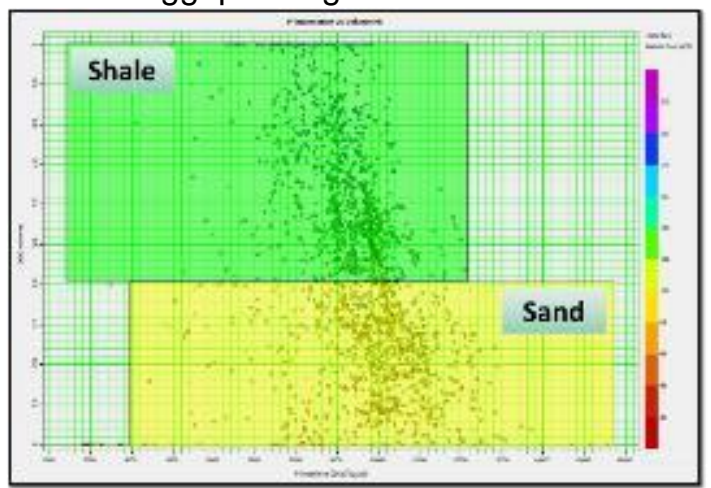

Gambar 16. Hasil crossplot analisis sensitivitas parameter P-Impedance vs V-shale dengan color key

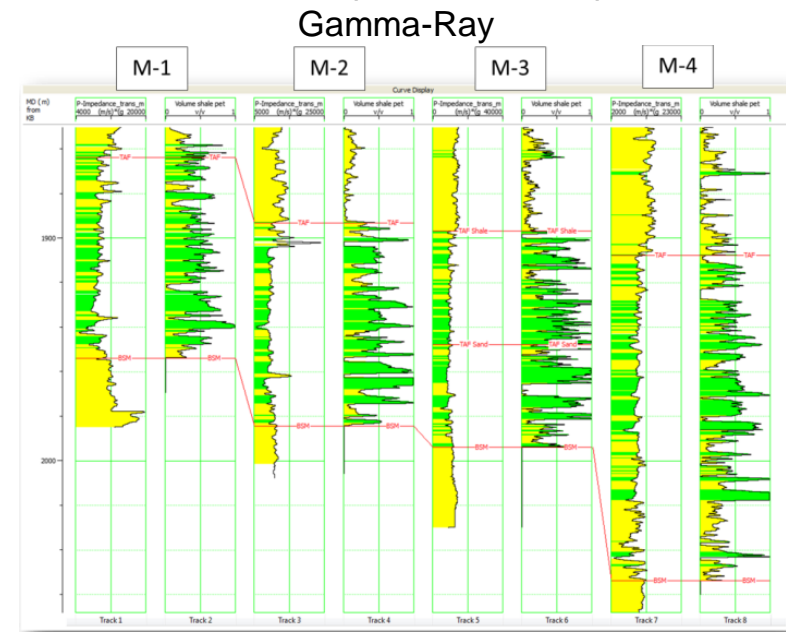

Gambar 17. Cross-section hasil analisis sensitivitas P-Impedance vs V-shale

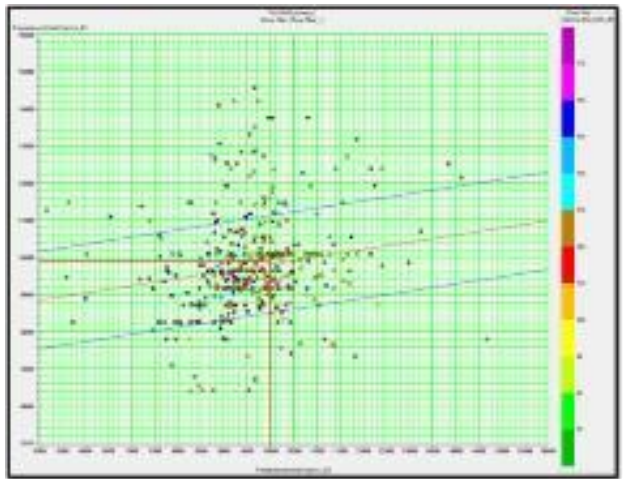

Gambar 18. Crossplot antara nilai hasil inversi stokastik pada posisi sumur dengan data log pada sumur untuk menentukan cut-off P-Impedance dengan color key Gamma-Ray

Untuk memetakan batupasir, kita memerlukan analisis nilai hasil inversi stokastik yang di-crossplot dengan nilai log pada sumur dan dikorelasikan untuk mendapatkan nilai cut-off batupasir. Setelah 
dilakukan crossplot, didapatkan hasil bahwa nilai cutoff untuk log P-Impedance adalah sebesar 10000 $(\mathrm{m} / \mathrm{s})^{*}(\mathrm{~g} / \mathrm{cc})$. Nilai cut-off yang telah didapatkan digunakan untuk mendapatkan probabilitas batupasir. Pada prinsipnya inversi seismik deterministik merupakan hasil perata-rataan (mean) dari semua realisasi yang telah dihasilkan pada inversi seismik stokastik.

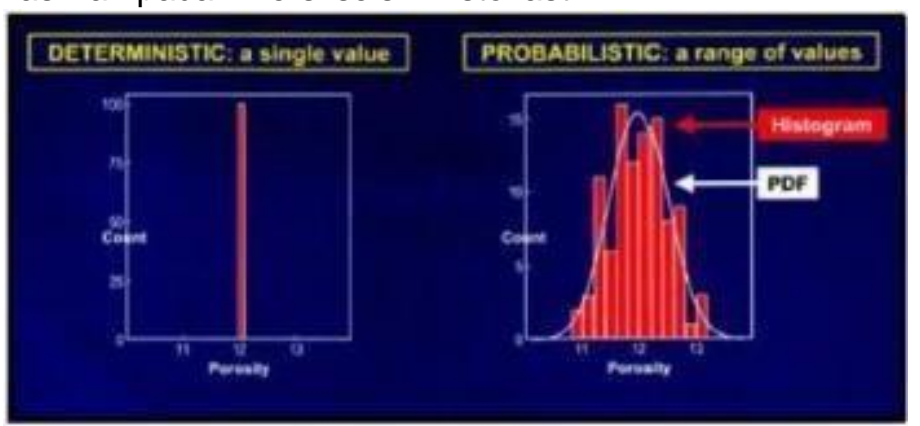

Gambar 19. Hubungan Inversi Seismik Deterministik dan Inversi Seismik Sokastik (Dubrule, 2003)

Dari Gambar 19. terlihat sebaran probabilitas nilai impedansi dimana inversi deterministik cenderung menghasilkan satu jawaban/ estimasi terbaik yang merupakan nilai mean atas sebaran kemungkinan. Sedangkan hasil inversi stokastik mencari realisasi nilai impedansi, dalam suatu range tertentu (berdasarkan pada standar deviasi sebaran tersebut). Maka dari gambar tersebut juga dapat menunjukkan suatu teorema bahwa inversi seismik deterministik merupakan rata-rata (mean) dari seluruh realisasi inversi seismik stokastik.

Penulis membandingkan hasil antara inversi seismik deterministik dengan mean hasil inversi seismik stokastik dan hasilnya menunjukkan bahwa hasil inversi deterministik memiliki kemiripan dan kecocokan dengan rata-rata dari 30 realisasi inversi stokastik sehingga jumlah realisasi 30 pada inversi stokastik sudah cukup mampu memberikan hasil yang mirip dengan hasil inversi seismik deterministik. Semakin banyak jumlah realisasi yang dihasilkan, mean realisasinya pun akan semakin menunjukkan kecocokan dengan hasil inversi seismik deterministik. Dengan demikian dapat dikatakan bahwa inversi seismik deterministik menampilkan hasil yang paling baik dan merupakan rata rata dari seluruh kemungkinan hasil dari inversi seismik stokastik. 

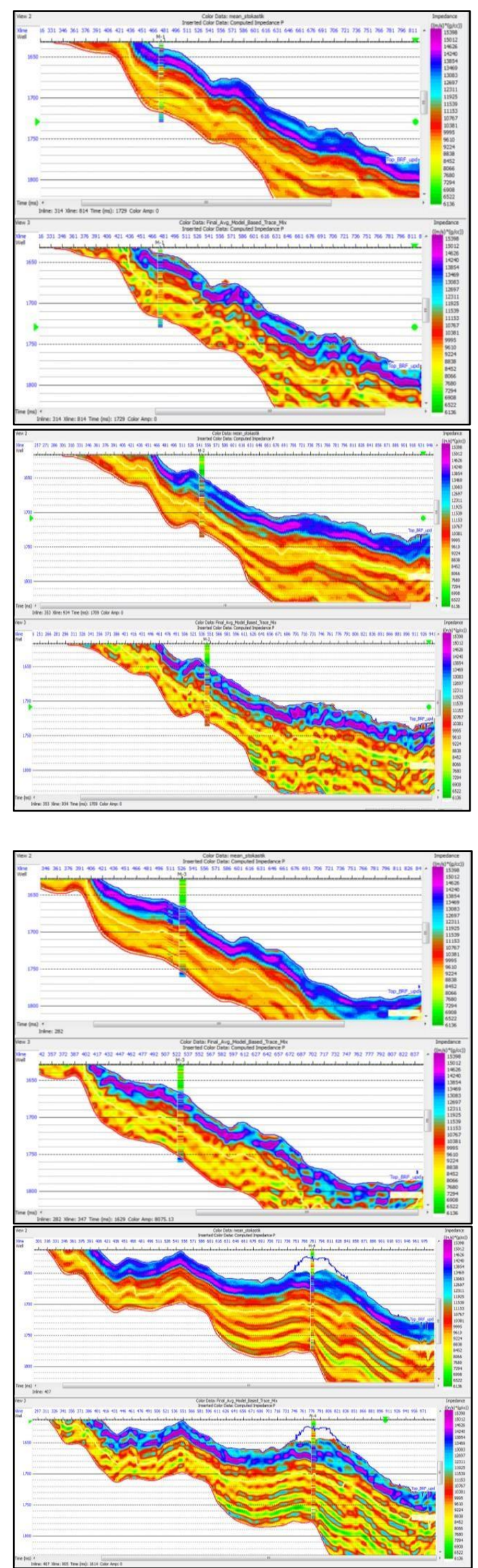

Gambar 20. Perbandingan hasil inversi mean stokastik (atas) dengan deterministik (bawah) melewati sumur M-1, M-2, M-3, M-4 


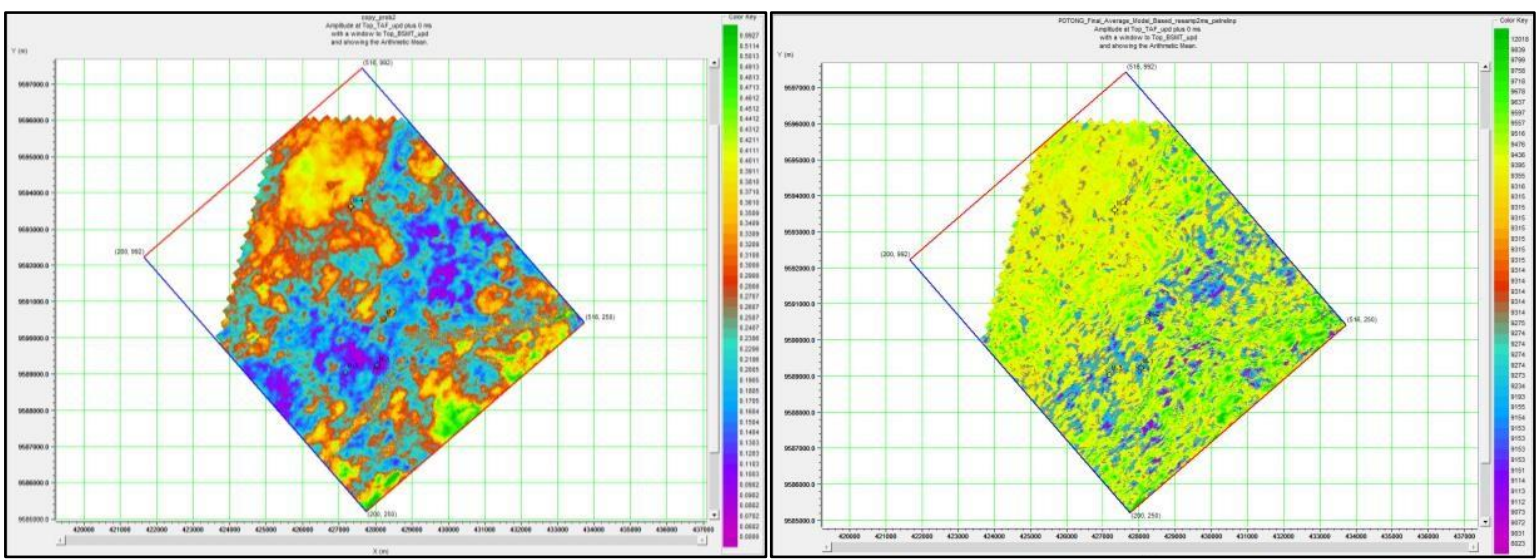

Gambar 21. Perbandingan peta mean model probabilitas batupasir (kiri) dengan peta mean dari inversi deterministik (kanan)

Terlihat dari gambar perbandingan peta mean model probabilitas batupasir dengan peta mean inversi deterministik yang menunjukkan bahwa apabila hanya menggunakan peta mean inversi deterministik saja yang merupakan peta rata-rata dari nilai impedansi akustik hasil inversi deterministik pada daerah target (antara horison Top_TAF_upd-Top_BSMT_upd), maka persebaran dari batupasir terlihat jelas tidak bisa ditentukan berdasarkan dari nilai impedansi akustiknya.

Sedangkan dengan menggunakan inversi seismik stokastik, dari sejumlah realisasi yang telah diperoleh, dibuat suatu model probabilitas dari range impedansi akustik batupasir. Maka melalui peta mean probabilitas, sebaran dari batupasir dapat terlihat dengan jelas dimana sebarannya ditunjukkan oleh probabilitas yang bernilai tinggi.

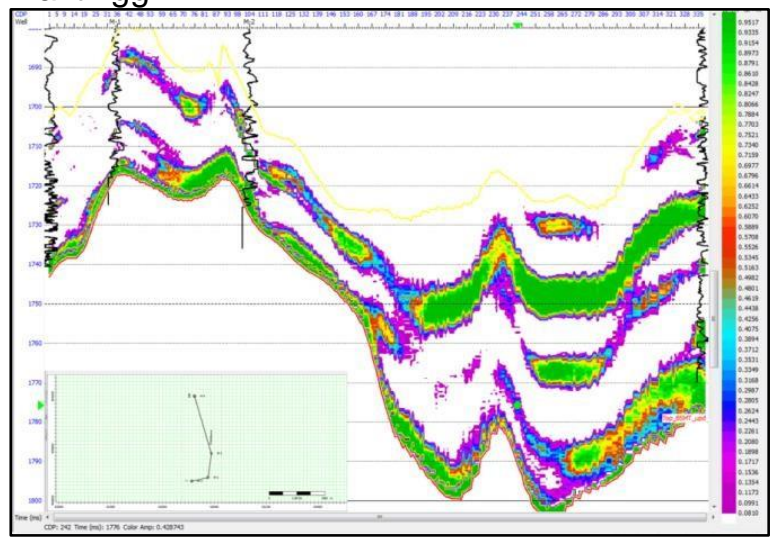

Gambar 22. Model Probabilitas batupasir berdasarkan nilai P-Impedance pada arbitrary line dengan kurva V-shale

Gambar 22. menunjukkan penampang persebaran batupasir di sepanjang arbitrary line yang dibuat sepanjang sumur M-1, M-2, M-3, dan M-4. Dari gambar tersebut menunjukkan kehadiran batupasir tersebut cocok dengan kurva V-shale, ketika V-shale memiliki nilai rendah, probabilitas batupasir tinggi maka dapat diartikan sebagai litologi batupasir. Probabilitas munculnya lapisan batupasir juga menunjukkan angka yang besar yaitu dengan rentang 0.081-0.9517.

Berdasarkan peta probabilitas batupasir terlihat bahwa pada bagian utara daerah penelitian cenderung lebih banyak terdapat batupasir dibandingkan daerah lainnya. Hal ini menunjukkan bahwa daerah berwarna kuning tersebut merupakan reservoir batupasir dengan probabilitas maksimum berdasarkan peta sayatan probabilitas batupasir. 


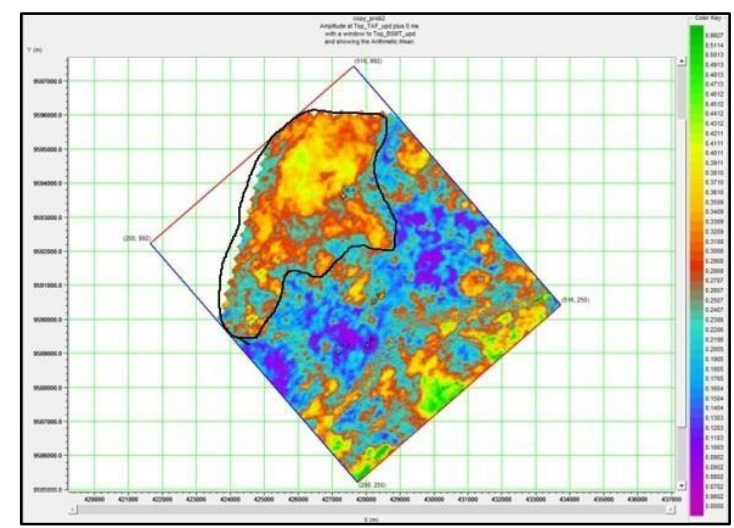

Gambar 23. Peta probabilitas batupasir

\section{Kesimpulan}

Parameter P-Impedance yang digunakan sebagai cut-off untuk memetakan persebaran probabilitas batupasir masih kurang cukup sensitif untuk memisahkan batupasir dengan shale.

Metoda inversi model based menghasilkan hasil yang cukup baik dan sesuai dengan data sumur, namun hasilnya masih cenderung smooth dan blocky sehingga belum mampu meresolusi lapisan tipis dengan baik.

Inversi seismik stokastik dapat diaplikasikan dengan baik pada reservoir batupasir di lapangan "M" dan menjadi pelengkap dari hasil inversi seismik deterministik. Inversi ini mampu mengatasi kekurangan yang ada pada inversi seismik deterministik khususnya pada kasus lapisan tipis.

Model probabilitas dari 30 realisasi inversi stokastik dengan parameter P-Impedance dapat memetakan persebaran reservoir batupasir di lapangan "M" dengan cukup baik. Peta probabilitas batupasir maksimum berada pada bagian utara daerah penelitian.

\section{Penghargaan}

Penulis menyampaikan terima kasih kepada ITB yang telah membantu mendukung penulis dalam menyelesaikan penelitian ini.

\section{Daftar Pustaka}

[1] Anstey, N.A., "Seismic Interpretation: The Physical Aspects,"IHRDC, 1977.

[2] Bishop, M.G., "South Sumatra Basin Province, Indonesia :The Lahat/ Talang Akar - Cenozoic Total Petroleum System, United State Geological Survey, 2001.

[3] Dubrule, O., "Geostatistics for Seismic Data Integration in Earth Models", Society of Exploration Geophysicist, 2003.

[4] Haas, A. and Dubrule, O., "Geostatistical inversion - a sequential method of stochastic reservoir modelling constrained by seismic data", First Break 12 (11) pp 561 - 569, 1994.

[5] De Coster, G.L., "The Geology of Central and South Sumatera Basins", Procceedings of the Indonesian Petroleum Association 3rd Annual Convention USA,1974. 